\title{
The Larval Stages of Simnia patula.
}

\author{
By \\ Marie V. Lebour, D.Sc., \\ Naturalist at the Plymouth Laboratory.
}

With 1 Text Figure and Plates 1-2.

Simnia patula (Pennant) $=$ Ovula is common feeding on Alcyonium digitatum and on Eunicella verrucosa, trawled in Plymouth waters. Mr. R. A. Todd records in the 1904 Plymouth Fauna List (Plymouth Marine Invertebrate Fauna, Journal of the Marine Biological Association, VII, 1904), which is quoted in the new fauna list (1931, Marine Biological Association), that "spawn probably belonging to this species has been found in April, June-July." This spawn is also well known to other members of the staft of the Laboratory and it is often found with the Simnia itself. It is now quite certain that it is the spawn of this mollusc, for it has been deposited in a plunger-jar on the glass and on Alcyonium (Jan. 19/20, 1932), and hatched out Feb. 21/22, 1932 ; it has been hatched out in the Laboratory, the larvæ distinguished in the plankton and reared until the crawling stage in a plunger-jar; and young stages which bridge the gulf from larva to adult have also been found. The adults will live for months in a plunger-jar feeding voraciously on Alcyonium. The life-history is described here for the first time. It is very interesting because it is quite unlike that of Trivia europea recently described (Lebour, 1931b), although the two are placed in the same family. Trivia bites holes in compound ascidians and lays its eggs in vase-shaped capsules embedded up to the neck in the ascidian, and these hatch out into larvæ having accessory shells rather like those of Lamellaria but with distinct differences. Simnia lays its eggs in a single layer of capsules, spreading over the Alcyonium for an inch or more in an irregular roundish mass (Text-figure 1).

Each capsule measures about $3.5 \mathrm{~mm}$. across and contains numerous eggs, the capsules sticking together in a tough, slightly yellowish, but nearly colourless, layer. Each capsule is roundish but inclined to be polygonal from the pressure of its neighbours. There is no accessory shell, and the first whorl of the embryonic shell before it leaves the egg is fully formed and of a dark brownish horn colour.

It was interesting to find that when these embryos were fixed in 
Bouin-Duboseq a film separated off from the shell, presumably the periostracum, forming a covering of exactly the shape of the accessory shell in Trivia (Plate 1, Fig. 3).

Very young larvæ occur in the plankton at a similar stage to those hatched in the Laboratory and from there onwards all free-swimming stages can be found. The later stages were kept until they lost the velum. A few later crawling stages were found in shelly gravel and on Alcyonium.

It is usually in the summer that the larvæ occur, and they may be very abundant, usually from outside the Breakwater but occasionally from inside.

In July, 1931, some spawn was placed in a plunger-jar and hatched out. The capsules were in several patches on the Alcyonium and probably

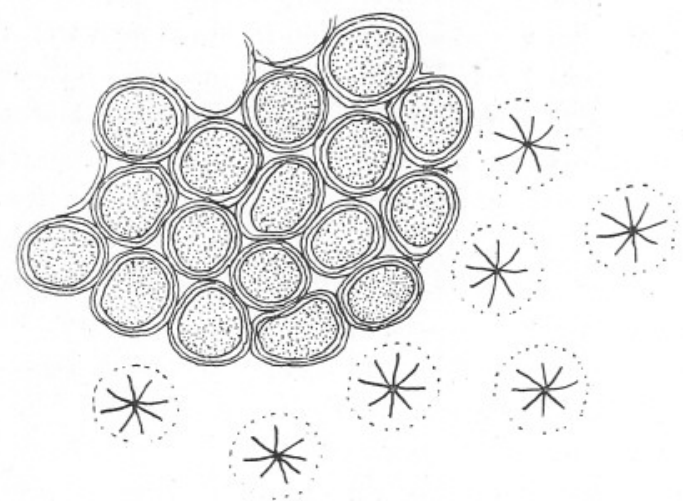

Text-Fig. 1.-Part of an egg mass of Simnia patula on Alcyonium.

were laid by different individuals. Some were newly laid, the eggs being unsegmented and of a pale yellowish-orange colour. These measured about $0.13 \mathrm{~mm}$. across. Others were hatching out and the larvæ inside the capsules were already veligers with a one-whorled shell. The newly hatched larva measures about $0 \cdot 14 \mathrm{~mm}$. or more across the widest part of the shell, the velum being bilobed with rounded lobes and measuring about $0.2 \mathrm{~mm}$. across. The shell is very opaque, dark brown with a granular irregular pattern all over it (Plate 1, Fig. 8). At the extreme outer lip it begins to be reticulated, and here there is a slight tooth-like outgrowth which grows into the characteristic tooth of the outer lip separating the two sinuses supporting the velum. The velum is quite colourless with long cilia bordering the top margin and an under-layer of smaller cilia below the groove which leads to the mouth from all round the velar edge. Eyes and short tentacles are prominent, and two large otocysts, also a broad foot with a thin horn-coloured operculum (Plate 1, Figs. 1-7). "It is not possible to see the internal organs owing to the thickness and 
opacity of the shell. Many hundred eggs occur in each capsule, all of which apparently develop. As the larva grows the shell continues to be reticulated with a coarse network, the pattern being all over except on the first whorl which is always differentiated by its granular surface. The animal protruding from the shell is a pale yellowish white, in the early stages with dark pigment round the mouth and on the sole of the foot which disappears as the animal grows. The velum is always colourless with no pigment at all in any stage, and soon becomes four-lobed, the lobes growing very long in the later stages. When the shell measures $0 \cdot 34 \mathrm{~mm}$. across at its widest part the velum is nearly a millimetre across, each lobe being nearly $0.50 \mathrm{~mm}$. long. When the shell is about $0.60 \mathrm{~mm}$. long, its largest measurement being now from the apex of the spine to the shell siphon, the velum measures $3 \mathrm{~mm}$. across, the lobes being long and narrow. At a length of $0.75 \mathrm{~mm}$. the shell has three whorls and a distinct shell siphon; the eyes are conspicuous, the tentacles long and ciliated at the tips; the foot projects beyond the shell and is more or less pointed at the hind part, rounded in front and ciliated all over. The head projects beyond the velum and a siphon is beginning to form. These late stages can either swim or crawl (Plate 1, Figs. 9-16). Placed in the plunger-jar they grew to about $0.80 \mathrm{~mm}$. in length and then began to lose the velum. At $0.96 \mathrm{~mm}$. the velum had quite gone and the mantle was beginning to spread over the shell. The siphon was long (Plate 2, Figs. 1-5). The tooth on the outer lip which had grown almost square and much inflexed now disappears; the operculum is lost; the reticulation of the shell are replaced by straight ribs; there are now four whorls. The embryonic shell grows no further. From now onwards radiating ribs are added and it is gradually grown over and finally disappears. A stage showing the embryonic shell with the adult shell growing from it in radiating ribs was found on an Alcyonium. This measured $1.12 \mathrm{~mm}$. in length from the tip of the spire to the shell siphon (Plate 2, Fig. 6). A later stage from shelly gravel, probably from an Alcyonium, showed the adult shell gradually spreading over the embryonic shell. This measured $1.84 \mathrm{~mm}$. in length (Plate 2, Figs. 7-8). The shell structure showed layers added on to one another with faint ribs very much like the structure of the adult. A still later stage from Alcyonium measuring $4.80 \mathrm{~mm}$. in length showed the complete absorbtion of the embryonic shell (Plate 2, Figs. 9-10). In this the animal and shell were like the adult, the mantle covering a large portion of the shell and having brown hair-like stripes separated by wide intervals.

It seems that Simnia must have a long larval life, for the late larvæ lived for several weeks in the plunger jar without losing the velum. The long velar lobes apparently indicate this, for all the shore forms which have a short larval life have a bilobed and very short velum for the whole 
of their free-swimming existence (Littorina littorea, Lacuna vincta, Rissoa membranacea and Rissoa parva). In shape the velum of Simnia is comparable to that of Nassarius incrassatus (see Lebour, 1931a) in which the larval life is very much prolonged and the crawling stage is not reached until the mollusc is of a considerable size.

These free-swimming larvæ of Simnia are important members of the outside plankton in summer, being amongst some of the largest planktonic mollusca seen, and at times they occur in great abundance with the larvæ of Nassarius incrassatus, these two larvæ being occasionally the only larval molluses present in the outside waters. Limacina retroversa is however very often found with them.

It is interesting to find in early descriptions of planktonic larval stages that Macdonald (1859) described the larval shells of Pedicularia, and these are very similar to the Simnia shells. Dautzenberg (1899) also figures young Pedicularia showing a similar reticulated embryonic shell. Pedicularia is closely related to Simnia, and in this way seems to be nearer to it than it is to Trivia. Simroth (1895) figures two planktonic larval shells which he thinks belong to Cypræa which again closely resemble the Simnia type. Both these facts are suggestive. It is perhaps possible that Simnia and Pedicularia are more closely related to Cypræa proper than to Trivia; and is Trivia, as Pelseneer (1926) suggests, more closely related to Lamellaria than to Cypræa?

\section{LITERATURE.}

Dautzenberg, P. 1899. Contributions à la Faune Malacologique des îles Açores. Res. Camp. Sci. Prince de Monaco, Fasc. 1, pp. 1-112.

Lebour, M. V. 1931a. The Larval Stages of Nassarius reticulatus and Nassarius incrassatus. Jour. Mar. Biol. Soc., N.S., XVII, 3, pp. $797-818$.

1931b. The Larval Stages of Trivia europea. Ibid., pp. 819-832.

Macdonald, J. D. 1859. On the Probable Metamorphoris of Pedicularia and other Forms; affording Presumptive Evidence that the Pelagic Gasteropoda, so called, are not adult forms, but, as it were, the Larvæ of well-known genera, and perhaps confined to species in deep water. Trans. Linn. Soc., Vol. XXII, pp. 241-243.

Pelseneer, P. 1926. Note d'embryologie malacologique. Ponte et développement de Cyprca europea, Trifora perversa et Lucina lactea. Bull. Biol. de la France et de la Belgique, LX, 1, pp. 88-112.

Simroth, H. 1895. Die Gasteropoden der Plankton Expedition. Ergebnisse der Plankton-Expedition der Humboldt-Stiftung. Bd. II, F. d., pp. 1-206. 



\section{PLATES 1-2. Simnia patula.}

(Scale B is six times the scale of A.)

PLATE 1 (1-7 scale B, 9-16 scale A, Fig. 8 is still more enlarged).

Fig. 1.-Newly hatched larva from egg, 0.14 mm. across.

, 2.-The shell of same.

, 3.-The same treated with Bouin-Duboscq, showing pellicle round shell.

, 4.-Larva three days old, shell $0.16 \mathrm{~mm}$. across.

," 5.-Shell of same.

, 6.-Operculum of same.

, 7.-Larva a few days old, from plankton, shell $0.18 \mathrm{~mm}$. across.

, 8.- Sculpture of embryonic shell much enlarged.

, 9.-Larval shell from plankton, $0 \cdot 24 \mathrm{~mm}$. across.

„, 10-13.-Larvæ with four-lobed velum from plankton : 10 , shell $0 \cdot 34 \mathrm{~mm}$. across :

11 , shell $0.4 \mathrm{~mm}$. across : 12 , shell $0.56 \mathrm{~mm}$. long : 13 , shell $0.75 \mathrm{~mm}$. long.

,, 14-16.-Larva crawling, losing velum. 
PLATE 1.
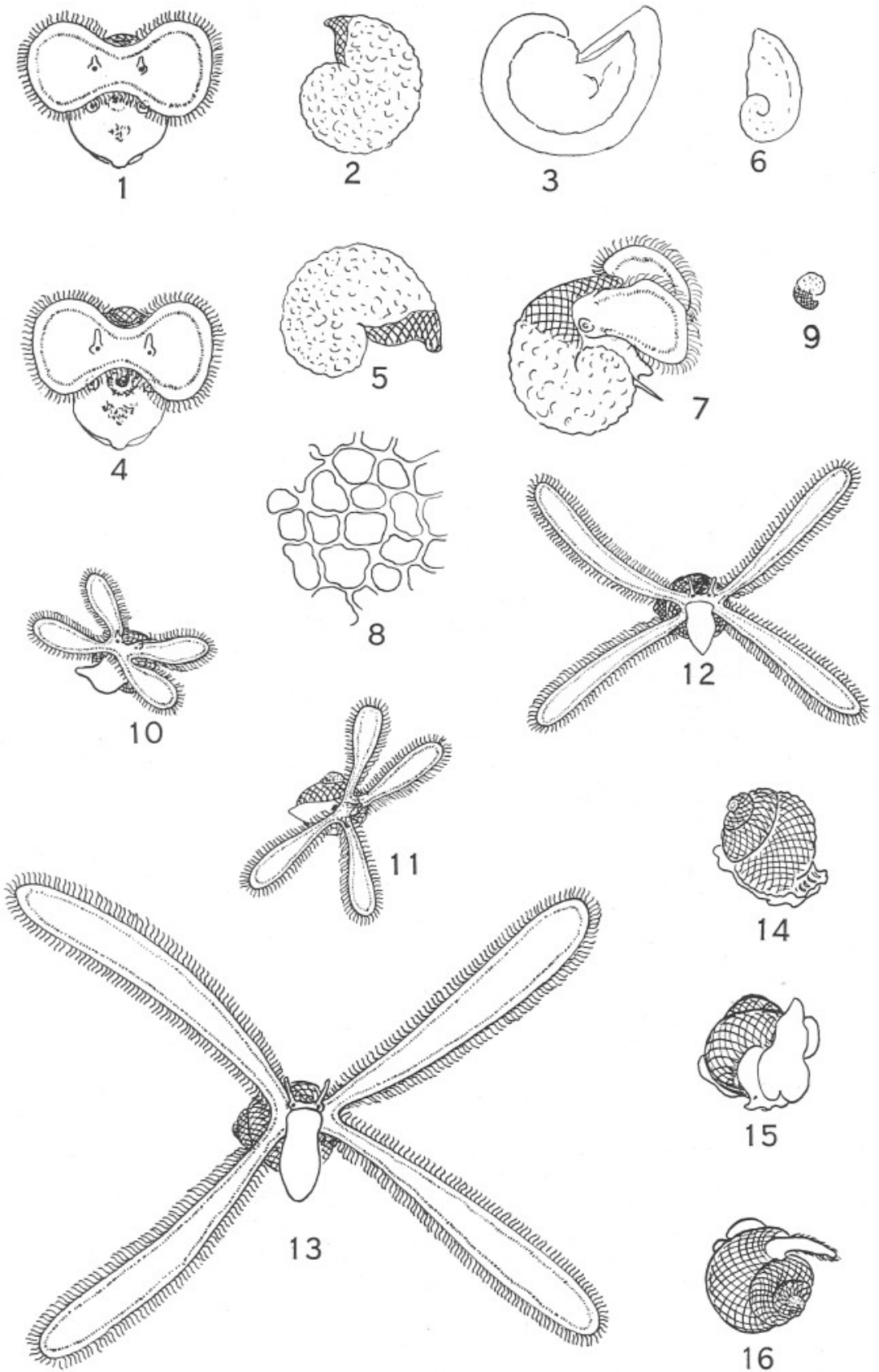
PLATE 2 (1-9 scale A, 10 on a smaller scale).

FIGS. 1, 2.-Shell of Simnia having lost velum, showing growth at mouth of shell filling up the velar sinuses.

, 3-5.- Simnia crawling, slightly later stages, reared from larva ${ }^{2}$ in plunger jar, 0.8 to $0.96 \mathrm{~mm}$. long.

, 6.- Later stage found feeding on Alcyonium, shell $1.12 \mathrm{~mm}$. long.

", 7-8.-Later stage, from shelly gravel, shell $1.84 \mathrm{~mm}$. long.

, 9-10.- Stage showing adult characters, shell $4.8 \mathrm{~mm}$. long, from Alcyonium. 
PLATE 2.
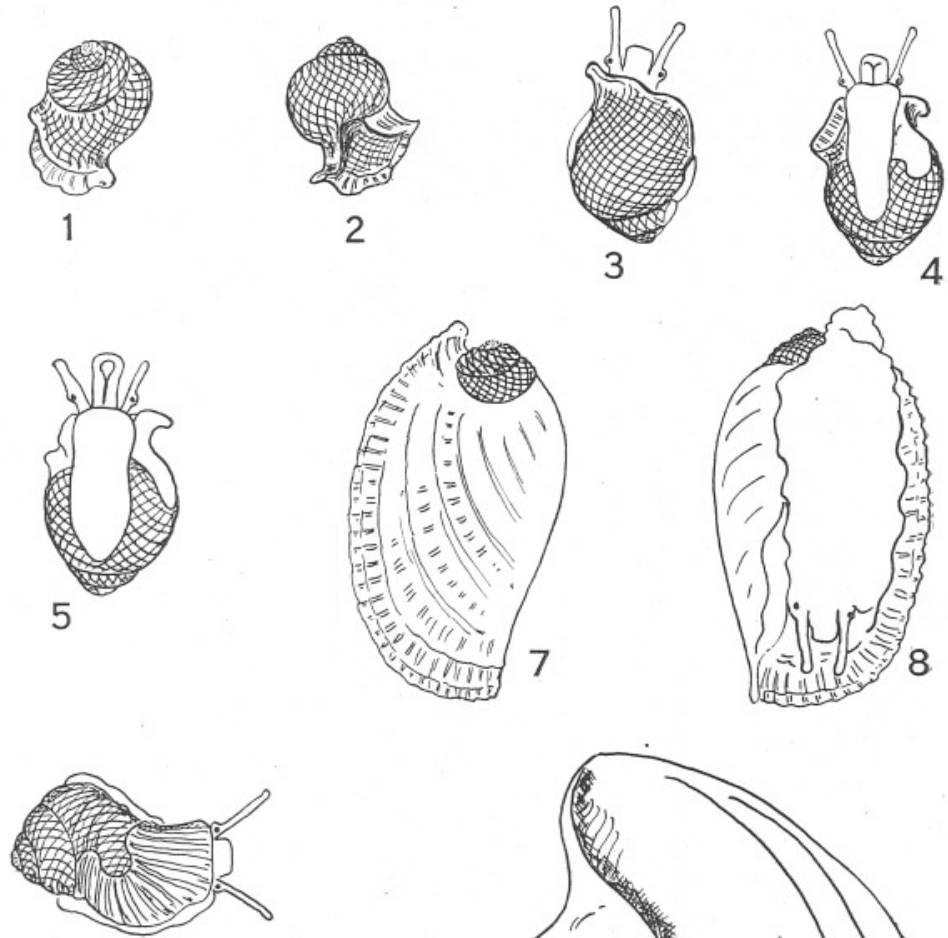

6
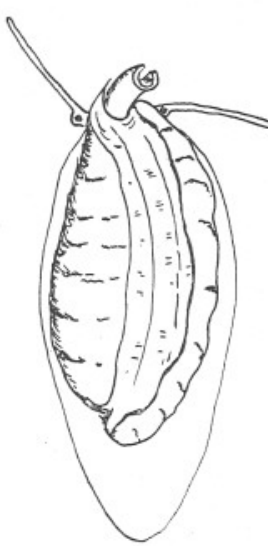

10

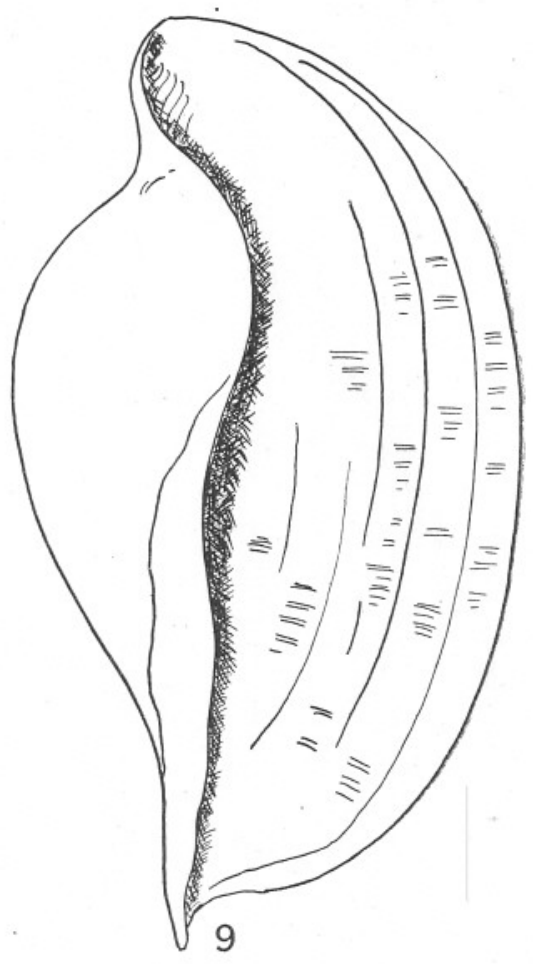


LIBRARY.
M.B.A.
PLYMOUTH. 